\title{
ВЛИЯНИЕ ДИКАЛИЕВЫХ СОЛЕЙ БЕНЗОИЛ ТАУРИНА НА ПРОСТАЦИКЛИН-КИНАЗНУЮ АКТИВНОСТЬ ИКОАГУЛЯЦИОННЫЙ ГЕМОСТАЗ ПИАЛЬНЫХ СОСУДОВ
}

\author{
В.Э. Пустынников, Н.В. Атапина, Ю.Н. Будаева, А.К. Брель
}

Кафедра фармакологии и фармации Института НМФО, ВолгГМУ, 400131, Россия, Волгоград, площадь Павших Борцов, д. 1.

DOI:10.19163/MedChemRussia2021-2021-269Ｅ-mail: Pustynnikov200122@gmail.com

В настоящее время нарушения мозгового кровообращения (НМК) являются одной из частых причин смертности и инвалидизации в развивающихся странах, чему способствует широкая распространенность патологий, при которых наблюдается склонность к тромбообразованию (сахарный диабет, атеросклероз, гипертония и др.). Улучшение микроциркуляции тканей головного мозга - одно из главных направлений лечения и профилактики острых и хронических НМК. Подобными свойствами могут обладать производные гидроксибензойной кислоты, для которых отмечено положительное влияние на скорость восстановления в условиях экспериментального НМК $[1,2,3]$. В связи с этим было изучено производное гидроксибензойной кислоты (С-60) намодели НМК посредством двусторонней окклюзии общих сонных артерии. В течение 7 дней после операции животные получали лечение соответственно группе: физ.р-р (контроль), С-60 и аспирин (препарат сравнения). Активность простациклин-синтетической системы оценивали по реакции пиальных сосудов на индометацин [4]. При измерении диаметра сосуда после внесения индометацина было отмечено, что курсовое введение С-60 и аспирин приблизительно в равной степени восстанавливают эндотелиальную функцию пиальных сосудов в условиях НМК. Также было обнаружено, что постишемические нарушения системы гемостаза связаны с нарушением функционирования простациклин-синтетической системы.

\section{Литература}

[1] Куркин Д.В., Волотова Е.В., Бакулин Д.А., и др. Влияние нового агониста рецептора GPR119 соединения ZB-16 на коагуляционный гемостаз крыс при экспериментальном сахарном диабете // Вестник Волгоградского государственного медицинского университета. 2016. № 1 (57). С. 48-51.

[2] Брель А.К., Тюренков И.Н., Лисина С.В., Будаева Ю.Н., Родина Н.В., Волотова Е.В., Куркин Д.В., Бакулин Д.А. Динатриевая соль салицилуровой кислоты, обладающая церебропротективной активностью. Патент на изобретение RU 2570644 C1, 10.12.2015. Заявка № 2014130538/04 от 23.07.2014.

[3] Брель А.К., Тюренков И.Н., Лисина С.В., Будаева Ю.Н., Родина Н.В., Волотова Е.В., Куркин Д.В., Бакулин Д.А. N-(4-ацетоксибензоил)глицинат калия, обладающий церебропротективным действием. Патент на изобретение RU 2556637 C1, 10.07.2015. Заявка № 2014115588/04 от 17.04.2014.

[4] Горшкова О.П., Ленцман М.В., Артемьева А.И., Дворецкий Д.П. Динамика изменения реактивности пиальных сосудов после кратковременной ишемии головного мозга // Регионарное кровообращение и микроциркуляция. 2015. - №1(53). - С.74-78 